\title{
Polymorphisms at GLUT1 Gene Are Not Associated With the Development of TSP/HAM in Brazilian HTLV-1 Infected Individuals and the Discovery of a New Polymorphism at GLUT1 Gene
}

\author{
Giselle Calasans Souza Costa, ${ }^{1}$ Rochele Azevedo, ${ }^{2}$ Sandra Rocha Gadelha, ${ }^{1}$ Simone Haddad Kashima, ${ }^{2}$ \\ Gabriel Muricy, ${ }^{3}$ Viviana Nila Olavarria, ${ }^{1}$ Dimas Tadeu Covas, ${ }^{2}$ Osvaldo Massaiti Takayanagui, ${ }^{4}$ \\ Bernardo Galvão-Castro, ${ }^{1,3}$ and Luiz Carlos Júnior Alcantara ${ }^{1,3 *}$ \\ ${ }^{1}$ Laboratório Avançado de Saúde Pública, Centro de Pesquisa Gonçalo Moniz, Fundação Oswaldo Cruz, \\ Salvador, Bahia, Brazil \\ ${ }^{2}$ Hemocentro de Ribeirão Preto, São Paulo, Brazil \\ ${ }^{3}$ Escola Bahiana de Medicina e Saúde Pública, Fundação Bahiana para o Desenvolvimento das Ciências, \\ Salvador, Bahia, Brazil \\ ${ }^{4}$ Universidade de São Paulo, Faculdade de Medicina de Ribeirão Preto, Departamento de Neurologia, \\ Psiquiatria e Psicologia Médica, São Paulo, Brazil
}

The development of HTLV-1 associated clinical manifestations, such as TSP/HAM and ATLL, occur in $2-4 \%$ of the infected population and it is still unclear why this infection remains asymptomatic in most infected carriers. Recently, it has been demonstrated that HTLV uses the Glucose transporter type 1 (GLUT1) to infect T-CD4 ${ }^{+}$ lymphocytes and that single nucleotide polymorphisms (SNP) in the GLUT1 gene are associated with diabetic nephropathy in patients with diabetes mellitus in different populations. These polymorphisms could contribute to a higher GLUT1 protein expression on cellular membrane, facilitating the entry of HTLV and its transmission cell by cell. This could result in a higher provirus load and consequently in the development of TSP/HAM. To evaluate the role of GLUT1 gene polymorphisms in the development of TSP/HAM in HTLV-1 infected individuals, the g.22999G $>$ T, g.15339T $>C$ and c.-2841A $>T$ sites were analyzed by PCR/RFLP or sequencing in 244 infected individuals and 102 normal controls. The proviral load of the HTLV-1 infected patients was also analyzed using Real Time Quantitative PCR. Genotypic and allelic frequencies of the three sites did not differ significantly between controls and HTLV-1 infected individuals. There was no difference in genotypic and allelic distributions among patients as to the presence or absence of HTLV-1 associated clinic manifestations. As regards the quantification of the provirus load, we observed a significant reduction in the asymptomatic individuals compared with the oligosymptomatic and TSP/HAM individuals.
These results suggest that g.22999G $>\mathrm{T}$, g.15339T $>$ C, and c.-2841A $>$ T SNP do not contribute to HTLV-1 infection nor to the genetic susceptibility of TSP/HAM in Brazilian HTLV-1 infected individuals. J. Med. Virol. 81:552557, 2009. (๖) 2009 Wiley-Liss, Inc.

\section{KEY WORDS: HTLV-1; GLUT1; polymor- phisms}

\section{INTRODUCTION}

The Human T-cell Lymphotropic Virus (HTLV) was discovered in 1980 [Poiesz et al., 1980; Yoshida et al., 1982]. This virus is associated with adult T-cell leukemia/lymphoma (ATLL) [Poiesz et al., 1980] and tropical spastic paraparesis/HTLV-1 associated myelopathy (TSP/HAM) [Gessain et al., 1985; Osame et al., 1986]. The HTLV-1 infection is endemic in various parts of the world, including Japan, Africa, and South America. In Brazil, the city of Salvador, capital of the state of Bahia, has the highest HTLV-1 seroprevalence $(1.76 \%)$ [Dourado et al., 2003].

Grant sponsor: Fundação de Amparo a Pesquisa do Estado da Bahia (FAPESB; partially supported).

*Correspondence to: Luiz Carlos Júnior Alcantara, Laboratório Avançado de Saúde Pública, Centro de Pesquisa Gonçalo Moniz, Fundação Oswaldo Cruz, Salvador, Rua Waldemar Falcão 121, Candeal, Salvador, Bahia 40296-610, Brazil.

E-mail: lalcan@bahia.fiocruz.br

Accepted 14 November 2008

DOI 10.1002/jmv.21421

Published online in Wiley InterScience

(www.interscience.wiley.com) 
The development of HTLV-1 associated clinic manifestations occurs in a small number of infected individuals $(2-4 \%)$. Furthermore, TSP/HAM and ATLL, HTLV-1 infection has been associated to uveitis [Mochizuki et al., 1992], arthritis [Kitajima et al., 1989], polymyositis [Morgan et al., 1989], and infective dermatitis [LaGrenade et al., 1990]. It is unclear why HTLV-1 infection remains asymptomatic in most infected carriers, while in some it presents a broad spectrum of disease manifestations.

It was recently discovered that HTLV envelope binding and virus entry occur as a result of a direct interaction with the glucose transporter type 1 (GLUT1), demonstrating that HTLV is able to use GLUT1 to infect T-CD4 ${ }^{+}$lymphocytes [Coskun and Sutton, 2005; Manel et al., 2005]. In 2005, Coskun and Sutton showed that GLUT1 expression increases susceptibility to HTLV. It has been suggested that cell-tocell HTLV transmission is facilitated by a virological synapse formation that accumulates HTLV structural proteins and T-cell activation markers between infected and non-infected cells [Bangham et al., 2003].

A G-to-T substitution at position +22999 in intron 2 of the GLUT1 gene (g.22999G > T polymorphism), which does not cause a protein modification, and an A-to- $T$ substitution at position -2841 (c.-2841A $>$ T polymorphism) in the promoter region of the same gene have been associated with susceptibility to diabetic nephropathy (DN) in patients with type 1 and type 2 diabetes mellitus in different populations [Gutierrez et al., 1998; Liu et al., 1998, 1999; Grzeszczak et al., 2001; Hodgkinson et al., 2005]. On the other hand, the g.15339T $>$ C polymorphism, located in the exon 2 of GLUT1 gene, does not cause any aminoacid change and it has not been associated with susceptibility to diabetic nephropathy [Ng et al., 2002].

Single nucleotide polymorphisms (SNP) at regulator and promoter regions of the GLUT1 gene, which have the potential to modulate the gene expression by location at transcription factors binding sites or by linkage disequilibrium with other functional polymorphisms, could influence the GLUT1 protein expression in the cell and therefore HTLV infection susceptibility. However, there are no studies in the literature focusing on the association of polymorphisms at GLUT1 gene with virus infection or manifestations. With regard to SNP, the increase in GLUT1 expression in the cell membrane could facilitate the entry of the virus and its cell-to-cell transmission, leading to a higher provirus load, and consequently to TSP/HAM development. In this context, GLUT1 gene polymorphisms could explain the different HTLV-1 associated disease manifestations and the asymptomatic status of most of the infected individuals.

To examine the role of GLUT1 gene polymorphisms in the development of TSP/HAM in HTLV-1 infected individuals, the g.22999G $>\mathrm{T}$, g.15339T $>\mathrm{C}$, and c. $-2841 \mathrm{~A}>\mathrm{T}$ sites were analyzed in infected and non-infected individuals. Additionally, the provirus load of HTLV-1 was also quantified in infected patients and compared with the genotypic and allelic frequencies.

\section{MATERIALS AND METHODS}

\section{Study Design and Population}

Two hundred and forty four DNA samples from HTLV-1 infected individuals were examined: 137 (77 asymptomatic individuals, 18 oligosymptomatic and 42 TSP/HAM) were seen at the HTLV Center/Medicine School of Bahia and Public Healthy/Foundation for Science Development, Salvador, Bahia, Brazil and 107 (59 asymptomatic individuals and $48 \mathrm{TSP} / \mathrm{HAM}$ ) were seen at the Hemocenter Foundation in Ribeirão Preto, São Paulo, Brazil. A total of 102 DNA samples from noninfected individuals were randomly selected from the general population of Salvador [Dourado et al., 2003] to obtain control frequencies. The local ethical committee's approval was obtained and all subjects provided written informal consent. The study group was classified according to their HTLV-1 clinical manifestations and infection. These are summarized as follows:

TSP/HAM patients $(\boldsymbol{n}=90) . \quad$ HTLV-1 infected individuals with a TSP/HAM diagnosis based on Osame's Motor Disability Score (OMDS): slowly progressive paraparesis caused by a symmetrical myelopathy involving predominantly the pyramidal tracts [Osame et al., 1986].

Oligosymptomatic patients $(\boldsymbol{n}=18) . \quad$ HTLV-1 infected individuals with some neurological manifestations but not fitting the TSP/HAM criteria based on OMDS.

Asymptomatic patients $(\boldsymbol{n}=136) . \quad$ HTLV- 1 infected individuals without any clinical manifestations associated to HTLV-1 infection.

Non-infected individuals $(\boldsymbol{n}=102)$. HTLV-1 non-infected individuals from the general population of Salvador.

\section{DNA Extraction and Single Nucleotide Polymorphism Detection}

Genomic DNA was extracted from peripheral blood mononuclear cells (PBMC) using a proteinase $\mathrm{K}$ treatment followed by a phenol-chloroform method. The analyses of the g.22999G $>\mathrm{T}$ and g.15339T $>\mathrm{C}$ polymorphisms were performed through PCR amplification followed by restriction fragment length polymorphism (RFLP) using primers and PCR conditions described previously [ $\mathrm{Ng}$ et al., 2002]. The resulting digested fragments from g.22999G $>$ T and g.15339T $>$ C polymorphisms were separated by gel electrophoresis on a $1.2 \%$ and $2.0 \%$ agarose gel respectively and scored under ultraviolet light. The c.- $2841 \mathrm{~A}>\mathrm{T}$ polymorphism analysis was performed in 180 samples (53 asymptomatic, 18 oligosymptomatic, $54 \mathrm{TSP} / \mathrm{HAM}$ and 55 normal controls) by sequencing using the following primers 5'GCTGAGAATGGCCTTCCCTCAAT3 ${ }^{\prime}$ and $5^{\prime}$ GTCTGCCTTACTCAGCCCATGGGTC $3{ }^{\prime}$. The measurement of the provirus load was performed in PBMC of 177 HTLV-1 
infected patients by Quantitative Real Time PCR as described previously [Dehee et al., 2003]. Briefly, SK110/SK111 primers were used to amplify a $186 \mathrm{pb}$ fragment of gene pool and dual TaqMan probe (5'FAM and $3^{\prime \prime T A M R A) ~ l o c a t e d ~ a t ~ 4,829-4,858 ~ b p ~ o f ~ t h e ~ H T L V-1 ~}$ reference sequence (HTLVATK). Albumin DNA was quantified in parallel in order to determine the input cell number and was used as an endogenous reference to avoid the variation due to differences in the PBMC count or DNA extraction. Standard curve was generated using 10 -fold serial dilution of a double plasmid (pcHTLVALB) congaing one copy of the target regions of both the HTLV-1 pol gene and the cellular albumin gene. The HTLV-1 infected human lymphocyte line MT2 was used as a control for quantification. All the samples (standard curve dilutions, the MT2 control samples, and the patient samples) were analyzed in duplicate for both HTLV-1 and albumin DNA quantification. The value for the HTLV-1 proviral load was reported as the [(HTLV-1 average copy number)/(albumin average copy number) $] \times 2 \times 10^{6}$ and expressed as the number of HTLV-1 copies per $10^{6}$ cells.

\section{Statistical Methods}

The allelic frequencies were estimated by direct allele counting. The conformity with Hardy-Weinberg equilibrium and existence of linkage disequilibrium were tested using the Genepop v.3.4 [Raymond and Rousset, 1995]. The heterogeneity among population samples was evaluated by Fisher's exact test or by $\chi^{2}$ test using the BioEstat v.4.0 program [Ayres et al., 2005]. MannWhitney $U$ test, also calculated using the BioEstat v.4.0 program [Ayres et al., 2005], was used to compare the median HTLV-1 provirus load in infected patients. A $P$-value $<0.05$ was considered statistically significant.

\section{RESULTS}

The studied population included HTLV-1 infected individuals from the cities of Salvador and Ribeirão Preto, Brazil and HTLV-1 non-infected individuals from the general population of Salvador. All analyses were performed separately in the HTLV-1 infected individuals from Salvador and Ribeirão Preto. There were no differences in genotypic and allelic frequencies of the GLUT1 gene polymorphisms studied when these populations were stratified (data not shown). For this reason, the HTLV-1 infected individuals from Salvador and Ribeirão Preto were studied in the same group.

The distribution of GLUT1 gene polymorphisms in 244 HTLV-1 infected individuals and 102 normal controls is shown in Table I. Genotypic frequencies of the analyzed sites did not differ significantly from those expected under Hardy-Weinberg equilibrium $\left(P=0.167, \chi^{2}=23.64\right)$. A strong linkage disequilibrium was observed when infected and non-infected individuals were compared together or as separate groups between the g.15339T $>\mathrm{C}$ polymorphism and g. $22999 \mathrm{G}>\mathrm{T}\left(\chi^{2}=37.870, P=0.001\right)$ and c. $-2841 \mathrm{~A}>\mathrm{T}$ $\left(\chi^{2}=\alpha, P<0.0001\right)$ polymorphisms. The median HTLV1 provirus load in the studied groups were: TSP/HAM = $35.466, \quad 5 \times 10^{6}, \quad \log _{10}=4.55 ; \quad$ oligosymptomatic $=$ $56.696 \times 10^{6}, \log _{10}=4.75$ and asymptomatic $=5.460 \times 10^{6}$, $\log _{10}=3.74$. The HTLV-1 provirus load was significantly smaller in asymptomatic carriers than in oligosymptomatic $(P=0.008)$ and TSP/HAM $(P<0.0001)$ patients. However, this result was not observed when oligosymptomatic and TSP/HAM individuals $(P=0.1489)$ were compared (data not shown). When the median provirus load was compared in HTLV-1 infected individuals with the genotypes from the analyzed polymorphisms, no statistically significant difference was observed (Fig. 1).

TABLE I. Genotypic and Allelic Frequencies of the g.22999G > T, g.15339T > C and c.-2841A > T Polymorphisms in HTLV-1 Infected and Non-Infected Individuals

\begin{tabular}{|c|c|c|c|c|c|c|}
\hline \multirow[b]{2}{*}{ g. $22999 \mathrm{G}>\mathrm{T}^{\mathrm{a}}$} & \multicolumn{4}{|c|}{ Genotypes } & \multicolumn{2}{|c|}{ Alleles } \\
\hline & $\mathrm{N}$ & $\mathrm{G} / \mathrm{G}(\%)$ & $\mathrm{G} / \mathrm{T}(\%)$ & $\mathrm{T} / \mathrm{T}(\%)$ & $\mathrm{G}(\%)$ & $\mathrm{T}(\%)$ \\
\hline Infected individuals & 244 & $89(36.5)$ & $126(51.6)$ & $29(11.9)$ & $304(62.3)$ & $184(37.7)$ \\
\hline \multirow[t]{2}{*}{ Non-infected individuals } & 102 & $29(28.4)$ & $57(55.9)$ & $16(15.7)$ & $115(56.4)$ & $89(43.6)$ \\
\hline & \multicolumn{4}{|c|}{ Genotypes } & \multicolumn{2}{|c|}{ Alleles } \\
\hline g. $15339 \mathrm{~T}>\mathrm{C}^{\mathrm{b}}$ & $\mathrm{N}$ & $\mathrm{T} / \mathrm{T}(\%)$ & $\mathrm{T} / \mathrm{C}(\%)$ & $\mathrm{C} / \mathrm{C}(\%)$ & $\mathrm{T}(\%)$ & $\mathrm{C}(\%)$ \\
\hline \multirow[t]{2}{*}{ Non-infected individuals } & $\begin{array}{l}244 \\
102\end{array}$ & $\begin{array}{c}17(7.0) \\
1(1.0)\end{array}$ & $\begin{array}{l}80(32.8) \\
36(35.3)\end{array}$ & $\begin{array}{c}147(60.2) \\
65(63.7)\end{array}$ & $\begin{array}{c}114(23.4) \\
38(18.6)\end{array}$ & $\begin{array}{l}374(76.6) \\
166(81.4)\end{array}$ \\
\hline & \multicolumn{4}{|c|}{ Genotypes } & \multicolumn{2}{|c|}{ Alleles } \\
\hline c. $-2841 \mathrm{~A}>\mathrm{T}^{\mathrm{c}}$ & $\mathrm{N}$ & $\mathrm{A} / \mathrm{A}(\%)$ & $\mathrm{A} / \mathrm{T}(\%)$ & $\mathrm{T} / \mathrm{T}(\%)$ & $\mathrm{A}(\%)$ & $\mathrm{T}(\%)$ \\
\hline $\begin{array}{l}\text { Infected individuals } \\
\text { Non-infected individuals }\end{array}$ & $\begin{array}{c}125 \\
55\end{array}$ & $36(28.8)$ & $61(48.8)$ & $28(22.4)$ & $133(53.2)$ & $117(46.8)$ \\
\hline
\end{tabular}

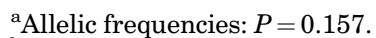

bAllelic frequencies: $P=0.222$.

cAllelic frequencies: $P=0.719$. 


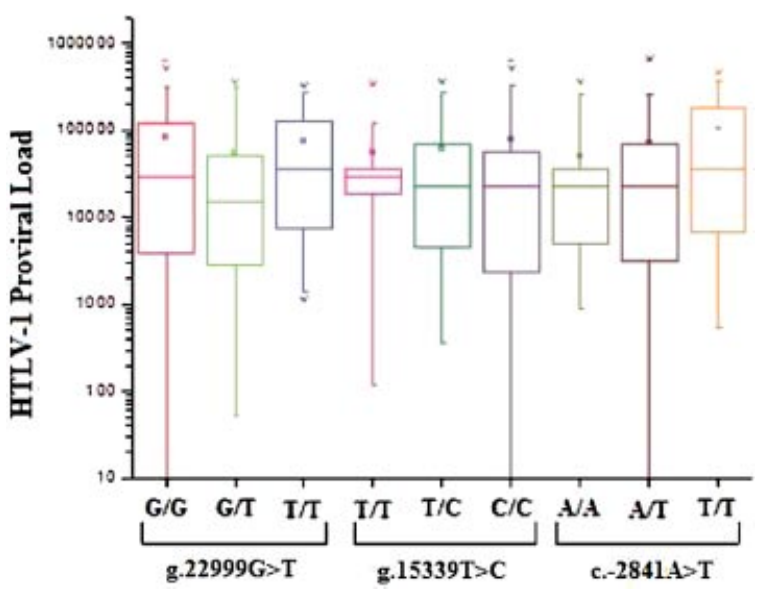

Fig. 1. Comparison of HTLV-1 provirus load of HTLV-1 infected individuals with g.22999G $>$ T, g.15339T $>$ C, and c.-2841A $>$ T genotypes. Median HTLV-1 copy numbers per $10^{6}$ PBMC determined by quantitative PCR are shown. The HTLV-1 provirus load did not differ between the genotypes from each polymorphic site analyzed $(P>0.05)$.

There were no differences in GLUT1 g.22999G > T, g. $15339 \mathrm{~T}>\mathrm{C}$, and c.-2841A $>\mathrm{T}$ genotypic and allelic distributions between HTLV-1 infected and noninfected individuals (Table I). No associations between the investigated polymorphisms and HTLV-1 associated disease manifestations were observed (Table II). Inclusion of asymptomatic and oligosymptomatic patients in the Non-TSP/HAM group did not alter the results: no differences in genotypic and allelic frequencies between TSP/HAM and Non-TSP/HAM patients were observed (data not shown).

In relation to the sequencing of the region corresponding to the c.-2841A > T polymorphism, a novel G-to-T substitution at -2807 position was found in 6 studied samples: 3 HTLV-1 infected individuals (2 TSP/HAM and 1 asymptomatic) and 3 non-infected individuals.

\section{DISCUSSION}

Many studies have demonstrated an association between polymorphisms at regulator and promoter regions of human genes and disease manifestation [Yoshikawa et al., 2002; Licastro et al., 2003; Sabouri et al., 2004]. In fact, it has been demonstrated that cytokine gene polymorphisms may affect protein production and lead to "high" or "low" cytokine production [Rosenwasser and Borish, 1997; Fishman et al., 1998; Sabouri et al., 2004] and also could affect marker inflammation levels [D'Aiuto et al., 2004]. Previous studies have demonstrated that polymorphism at IL-6 and IL-10 promoters, at position -634 and -592 respectively, could play a role in the pathogenesis of HAM/TSP [Nishimura et al., 2002; Sabouri et al., 2004; Gadelha et al., 2008]. It has also been demonstrated that single nucleotide polymorphisms (SNP) and haplotype frequencies, can differ in populations with different ethnic backgrounds [Fishman et al., 1998; Cox et al., 2001; Hoffmann et al., 2002; Plothow et al., 2003; Gadelha et al., 2005].

In relation to single nucleotide polymorphisms (SNP) at GLUT1 gene, it has been suggested that they could influence the GLUT1 protein expression in the cell leading to a high or low protein production. These different phenotypes of protein production could be related to its functionality and affect its activity at cell membrane, related to glucose transport (GLUT1 primordial function) or to HTLV entry. In fact, some studies suggest that these GLUT1 human gene polymorphisms affect, either directly or indirectly, the protein glucose transport function and are related to the development of pathologies associated to glucose accumulation or absence in the cell [Liu et al., 1998, 1999; Grzeszczak et al., 2001; Hodgkinson et al., 2005].

As regards HTLV-1 infection, this is the first study that analyses SNP in GLUT1 gene, virus infection

TABLE II. Genotypic and Allelic Frequencies of the g.22999G > T, g.15339T > C, and c.-2841A > T Polymorphisms in HTLV-1 Infected Individuals (Asymptomatic and TSP/HAM)

\begin{tabular}{|c|c|c|c|c|c|c|}
\hline \multirow[b]{2}{*}{ g. $22999 \mathrm{G}>\mathrm{T}$} & \multicolumn{4}{|c|}{ Genotypes } & \multicolumn{2}{|c|}{ Alleles } \\
\hline & $\mathrm{N}$ & $\mathrm{G} / \mathrm{G}(\%)$ & $\mathrm{G} / \mathrm{T}(\%)$ & $\mathrm{T} / \mathrm{T}(\%)$ & $\mathrm{G}(\%)$ & $\mathrm{T}(\%)$ \\
\hline Asymptomatic $^{\mathrm{a}}$ & 136 & $46(33.8)$ & $74(54.4)$ & $16(11.8)$ & $166(61.0)$ & $106(39.0)$ \\
\hline \multirow[t]{2}{*}{$\mathrm{TSP} / \mathrm{HAM}^{\mathrm{a}}$} & 90 & $32(35.6)$ & $46(51.1)$ & $12(13.3)$ & $110(61.1)$ & $70(38.9)$ \\
\hline & \multicolumn{4}{|c|}{ Genotypes } & \multicolumn{2}{|c|}{ Alleles } \\
\hline g. $15339 \mathrm{~T}>\mathrm{C}$ & $\mathrm{N}$ & $\mathrm{T} / \mathrm{T}(\%)$ & $\mathrm{T} / \mathrm{C}(\%)$ & $\mathrm{C} / \mathrm{C}(\%)$ & $\mathrm{T}(\%)$ & $\mathrm{C}(\%)$ \\
\hline Asymptomatic $^{\mathrm{b}}$ & 136 & $10(7.3)$ & $36(26.5)$ & $90(66.2)$ & $56(20.6)$ & $216(79.4)$ \\
\hline \multirow[t]{2}{*}{$\mathrm{TSP} / \mathrm{HAM}^{\mathrm{b}}$} & 90 & $5(5.6)$ & $37(41.1)$ & $48(53.3)$ & $47(26.1)$ & $133(73.9)$ \\
\hline & \multicolumn{4}{|c|}{ Genotypes } & \multicolumn{2}{|c|}{ Alleles } \\
\hline c. $-2841 \mathrm{~A}>\mathrm{T}$ & $\mathrm{N}$ & $\mathrm{A} / \mathrm{A}(\%)$ & $\mathrm{A} / \mathrm{T}(\%)$ & $\mathrm{T} / \mathrm{T}(\%)$ & $\mathrm{A}(\%)$ & $\mathrm{T}(\%)$ \\
\hline Asymptomatic & 53 & $14(26.4)$ & $29(54.7)$ & $10(18.9)$ & $57(53.8)$ & $49(46.2)$ \\
\hline $\mathrm{TSP} / \mathrm{HAM}^{\mathrm{c}}$ & 54 & $18(33.3)$ & $23(42.6)$ & $13(24.1)$ & $59(54.6)$ & $49(45.4)$ \\
\hline
\end{tabular}

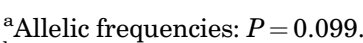

bAllelic frequencies: $P=0.171$.

${ }^{\mathrm{c}}$ Allelic frequencies: $P=0.900$. 
susceptibility and the development of associated diseases. As only a subset of HTLV-1 infected individuals develops TSP/HAM or ATLL, a difference might exist in GLUT1 protein activity and viral and carriers factors among those who are susceptible to disease development and those who are not. This difference can be caused by a protein variant or by a polymorphism in the regulatory part of the gene involved in its expression.

It has been previously demonstrated that a high HTLV-1 proviral load is associated with an increased risk of progression to disease [Nagai et al., 1998], progression of motor disability [Takenouchi et al., 2003], and risk of sexual transmission of HTLV-1 [Kaplan et al., 1996]. In TSP/HAM patients from Japan, the median provirus load in peripheral blood mononuclear cells (PBMC) is more than ten times higher than in asymptomatic patients [Nagai et al., 1998]. In this study, it was observed that the median HTLV-1 provirus load is smaller in asymptomatic carriers than in oligosymptomatic and TSP/HAM patients suggesting that this aspect of HTLV-1 infection is associated with the development of neurological symptoms. However, we did not observe any association between the genotypes frequencies from the analyzed polymorphisms and the proviral load.

The g.15339T $>$ C polymorphism is located in the exon 2 of GLUT1 gene and it does not cause any aminoacid change [Ng et al., 2002]. These results did not demonstrate an association between allelic and genotypic frequencies of this polymorphism and the risk of TSP/ HAM development.

The c.-2841A $>$ T polymorphism is located next to a HIF-responsive element in the GLUT1 promoter that has the capacity to up-regulate GLUT1 expression in hypoxic conditions [Hayashi et al., 2004]. It has been recently demonstrated that Tax (HTLV-1 regulatory protein) mediates the HIF-1(Hypoxia-inducible factor1) transcriptional activation by Phosphatidylinositol 3-kinase (PI3K)/AKT signaling pathway [Tomita et al., 2007]. This mechanism could induce GLUT1 expression in HTLV-1 infected cells and facilitate its transmission. In this study, no association between c.-2841A $>$ T polymorphism and TSP/HAM development was observed. The novel c.-2807G $>$ T mutation was observed in $1.7 \%$ of the population studied, characterizing this mutation as a polymorphic site.

The g.22999G $>$ T polymorphism has been associated to susceptibility to diabetic nephropathy in different populations [Liu et al., 1998, 1999; Gutierrez et al., 1998; Grzeszczak et al., 2001]. The observed results did not demonstrate any difference in genotypic and allelic frequencies between HTLV-1 infected and non-infected individuals and between HTLV-1 infected patients with a different clinic status. The association of g.22999G $>$ T polymorphism and diabetic nephropathy has been suggested to be caused by linkage disequilibrium with other functional disease markers, since this polymorphism occurs in the intron 2 of GLUT1 gene and does not cause a protein modification [Grzeszczak et al., 2001]. In this study, a strong linkage disequilibrium of
g.22999G $>\mathrm{T}$ and g.15339T $>\mathrm{C}$ polymorphisms was observed. However, as previously shown, both polymorphisms are not associated with TSP/HAM development in our population and they can not be used as markers of this pathology.

These results suggest that the g. $22999 \mathrm{G}>\mathrm{T}$, g. $15339 \mathrm{~T}>\mathrm{C}$, and c.-2841A $>\mathrm{T}$ polymorphisms at GLUT1 gene, although probably related to glucose entry in the cell (g.22999G $>\mathrm{T}$ and c.-2841A $>\mathrm{T}$ polymorphisms), are not associated with HTLV-1 infection nor with TSP/HAM development, suggesting that the different activities of the GLUT1 protein (glucose transport and HTLV entry) are mediated by the protein distinct domains. However, more studies concentrated in the GLUT1 protein expression should be taken in order to investigate its major role in the development of TSP/HAM in HTLV-1 infected individuals.

\section{ACKNOWLEDGMENTS}

The authors are grateful to Noilson Lázaro de Souza Gonçalves for their technical assistance. We thank Maurício Barreto and Gloria Teixeira for the study design of the non-infected individuals and to Ceuci Nunes for the clinical evaluation.

\section{REFERENCES}

Ayres M, Ayres M Jr, Ayres DL, Santos AS. 2005. BioEstat. Versão 4.0, Sociedade Civil Mamirauá. Brasil: MCT-CNPq, Belém, Par.

Bangham CR, Stinchcombe JC, Goon PK, Taylor GP, Weber JN, Griffiths GM, Tanaka Y, Osame M, Igakura T. 2003. Spread of HTLV-I between lymphocytes by virus-induced polarization of the cytoskeleton. Science 299:1713-1716.

Coskun AK, Sutton RE. 2005. Expression of glucose transporter 1 confers susceptibility to human T-cell leukemia virus envelopemediated fusion. J Virol 79:4150-4158.

Cox ED, Hoffmann SC, DiMercurio BS, Wesley RA, Harlan DM, Kirk $\mathrm{AD}$, Blair PJ. 2001. Cytokine polymorphic analyses indicate ethnic differences in the allelic distribution of interleukin-2 and interleukin-6. Transplantation 72:720-726.

D'Aiuto F, Parkar M, Brett PM, Ready D, Tonetti MS. 2004. Gene polymorphisms in pro-inflammatory cytokines are associated with systemic inflammation in patients with severe periodontal infections. Cytokine 28:29-34.

Dehee A, Cesaire R, Desire N, Lezin A, Bourdonne O, Bera O, Plumelle Y, Smadja D, Nicolas JC. 2003. Quantitation of HTLV-I proviral load by a TaqMan real-time PCR assay. J Virol Methods 102:37-51.

Dourado I, Alcantara LC, Barreto ML, da Gloria Teixeira M, GalvaoCastro B. 2003. HTLV-I in the general population of Salvador, Brazil: A city with African ethnic and sociodemographic characteristics. J Acquir Immune Defic Syndr 34:527-531.

Fishman D, Faulds G, Jeffery R, Mohamed-Ali V, Yudkin JS, Humphries S, Woo P. 1998. The effect of novel polymorphisms in the interleukin-6 (IL-6) gene on IL-6 transcription and plasma IL-6 levels, and an association with systemic-onset juvenile chronic arthritis. J Clin Invest 102:1369-1376.

Gadelha SR, Alcantara LC, Costa GC, Rios DL, Galvao-Castro B. 2005. Ethnic differences in the distribution of interleukin- 6 polymorphisms among three Brazilian ethnic groups. Hum Biol 77:509-514.

Gadelha SR, Alcântara LCJ, Costa GCS, Acosta AX, Rios DL, Kashima S, Covas D, Galvão-Castro B. 2008. Correlations between polymorphisms at interleukin- 6 but not at Interleukin-10 promoter and the risk of human T lymphotropic virus type I-associated myelopathy/tropical spastic paraparesis in Brazilian individuals. J Med Virol 12:2141-2146.

Gessain A, Barin F, Vernant JC, Gout O, Maurs L, Calender A, Thé G. 1985. Antibodies to human T lymphotropic virus type-I in patients with tropical spastic paraparesis. Lancet 2:407-410. 
Grzeszczak W, Moczulski DK, Zychma M, Szczechowska E, Trautsolt W, Szydlowska I. 2001. Role of GLUT1 gene in susceptibility to diabetic nephropathy in type 2 diabetes. Kidney Int 59:631-636.

Gutierrez C, Vendrell J, Pastor R, Broch M, Aguilar C, Llor C, Simon I, Richart C. 1998. GLUT1 gene polymorphism in non-insulin dependent diabetes mellitus: Genetic susceptibility relationship with cardiovascular risk factors and microangiopathic complications in a Mediterranean population. Diabetes Res Clin Pract 41:113-120.

Hayashi M, Sakata M, Takeda T, Yamamoto T, Okamoto Y, Sawada K, Kimura A, Minekawa R, Tahara M, Tasaka K, Murata Y. 2004. Induction of glucose transporter 1 expression through hypoxiainducible factor $1 \alpha$ under hypoxic conditions in trophoblast-derived cells. J Endocrinol 183:145-154.

Hodgkinson AD, Page T, Millward BA, Demaine AG. 2005. A novel polymorphism in the $5^{\prime}$ flanking region of the glucose transporter (GLUT1) gene is strongly associated with diabetic nephropathy in patients with type 1 diabetes mellitus. J Diabet Complications 19: $65-69$.

Hoffmann SC, Stanley EM, Cox ED, DiMercurio BS, Koziol DE, Harlan DM, Kirk AD, Blair PJ. 2002. Ethnicity greatly influences cytokine gene polymorphism distribution. Am J Transplant 2:560-567.

Kaplan JE, Khabbaz RF, Murphy EL, Hermansen S, Roberts C, Lal R, Heneine W, Wright D, Matijas L, Thomson R, Ruduloph D, Switzer WM, Kleinman S, Busch M, Schreiber GB. 1996. Male-to-female transmission of human T-cell lymphotropic virus types 1 and 2 : Association with viral load. The Retrovirus Epidemiology Donor Study Group. J Acquir Immune Defic Syndr Hum Retrovirol 12: 193-201.

Kitajima I, Maruyama I, Maruyama Y, Ijichi S, Eiraku N, Mimura Y, Osame M. 1989. Polyarthritis in human T lymphotropic virus type I-associated myelopathy. Arthritis Rheum 32:1342-1344.

LaGrenade L, Hanchard B, Fletcher V, Cranston B, Blattner W. 1990. Infective dermatitis of Jamaican children: A marker for HTLV-I infection. Lancet 336:1345-1347.

Licastro F, Grimaldi LM, Bonafe M, Martina C, Olivieri F, Cavallone L, Giovanietti S, Masliah E, Franceschi C. 2003. Interleukin-6 gene alleles affect the risk of Alzheimer's disease and levels of the cytokine in blood and brain. Neurobiol Aging 24:921-926.

Liu Z, Guan T, Chen Z. 1998. Insulin receptor substrate-1 and glucose transporter gene polymorphisms in noninsulin-dependent diabetes mellitus. Zhonghua Yi Xue Za Zhi 78:662-665.

Liu ZH, Guan TJ, Chen ZH, Li LS. 1999. Glucose transporter (GLUT1) allele (XbaI-) associated with nephropathy in non-insulin-dependent diabetes mellitus. Kidney Int 55:1843-1848.

Manel N, Battini JL, Sitbon M. 2005. Human T cell leukemia virus envelope binding and virus entry are mediated by distinct domains of the glucose transporter GLUT1. J Biol Chem 280:29025-29029.

Mochizuki M, Yamaguchi K, Takatsuki K, Watanabe T, Mori S, Tajima K. 1992. HTLV-I and uveitis. Lancet 339:1110.

Morgan OS, Rodgers-Johnson P, Mora C, Char G. 1989. HTLV-1 and polymyositis in Jamaica. Lancet 2:1184-1187.

Nagai M, Usuku K, Matsumoto W, Kodama D, Takenouchi N, Moritoyo T, Hashiguchi S, Ichinose M, Bangham CR, Izumo S, Osame M.
1998. Analysis of HTLV-1 proviral load in $202 \mathrm{HAM} / \mathrm{TSP}$ patients and 243 asymptomatic HTLV-1 carriers: High proviral load strongly predisposes to HAM/TSP. J Neurovirol 4:586-593.

Ng DP, Canani L, Araki S, Smiles A, Moczulski D, Warram JH, Krolewski AS. 2002. Minor effect of GLUT1 polymorphisms on susceptibility to diabetic nephropathy in type 1 diabetes. Diabetes 51:2264-2269.

Nishimura M, Matsuoka M, Maeda M, Mizuta I, Mita S, Uchino M, Matsui M, Kuroda Y, Kawakami H, Kaji R, Adachi A, Uchiyama T. 2002. Association between interleukin-6 gene polymorphism and human T-cell leukemia virus type I associated myelopathy. Hum Immunol 63:696-700.

Osame M, Usuku K, Izumo S, Ijichi N, Amitani H, Igata A, Matsumoto M, Tara M. 1986. HTLV-I associated myelopathy, a new clinical entity. Lancet 1:1031-1032.

Plothow A, Benvenutti R, Contieri FL, Bicalho MG. 2003. Frequencies at three polymorphic sites of Interleukin-10 gene promoter in Brazilian renal recipients. Transplant Proc 35:2908-2910.

Poiesz BJ, Ruscetti FW, Gazdar AF, Bunn PA, Minna JA, Gallo RC. 1980. Detection and isolation of type $\mathrm{C}$ retrovirus particles from fresh and cultured lymphocites of a patient with cutaneous T-cell lymphoma. Proc Natl Acad Sci USA 77:7415-7419.

Raymond M, Rousset F. 1995. GENEPOP (version 1.2): Population genetics software for exact tests and ecumenicism. J Hered 86:248249 .

Rosenwasser LJ, Borish L. 1997. Genetics of atopy and asthma: The rationale behind promoter-based candidate gene studies (IL-4 and IL-10). Am J Respir Crit Care Med 156:152-155.

Sabouri AH, Saito M, Lloyd AL, Vine AM, Witkover AW, Furukawa Y, Izumo S, Arimura K, Marshall SEF, Usuku K, Bangham CRM, Osame M. 2004. Polymorphism in the interleukin-10 promoter affects both provirus load and the risk of human T lymphotropic virus type I-associated myelopathy/tropical spastic paraparesis. J Infect Dis 190:1279-1285.

Takenouchi N, Yamano Y, Usuku K, Osame M, Izumo S. 2003. Usefulness of proviral load measurement for monitoring of disease activity in individual patients with human T-lymphotropic virus type 1-associated myelopathy/tropical spastic paraparesis. J Neurovirol 9:29-35.

Tomita M, Semenza GL, Michiels C, Matsuda T, Uchihara J, Okudaira T, Tanaka Y, Taira N, Ohshiro K, Mori N. 2007. Activation of hypoxia-inducible factor 1 in human T-cell leukemia virus type 1 infected cell lines and primary adult T-cell leukemia cells. Biochem J 406:317-323.

Yoshida M, Miyoshi I, Hinuma Y. 1982. Isolation and characterization of retrovirus from cell lines of human adult T-cell leukemia and its implication in the disease. Proc Natl Acad Sci USA 79:20312035.

Yoshikawa T, Kitamura A, Hasegawa G, Obayashi H, Kamiuchi K, Ishii M, Yano M, Tanaka T, Yamaguchi M, Shigeta H, Ogata M, Nakamura N. 2002. Interleukin-6 polymorphism $(-634 \mathrm{C} / \mathrm{G})$ in the promotor region and the progression of diabetic nephropathy in type 2 diabetes. Diabetic Med 19:1000-1005. 